\title{
HYDROGEOLOGICAL STUDY OF THE MALENŠČICA KARST SPRING (SW SLOVENIA) BY MEANS OF A TIME SERIES ANALYSIS
}

\section{HIDROGEOLOŠKA ŠTUDIJA KRAŠKEGA IZVIRA MALENŠČICA (JZ SLOVENIJA) Z METODO ANALIZE ČASOVNIH VRST}

\author{
Gregor KOVAČIČ́
}

\begin{abstract}
UDC 556.33(497.4)

Gregor Kovačič: Hydrogeological study of the Malenščica karst spring (SW Slovenia) by means of a time series analysis Time series analyses are often used for the investigation of karst aquifers, but are only rarely employed in a way of using a large number of spatially distributed time series. Furthermore, only a small number of applications employ other types of hydrological data apart from rainfall, water level and discharge. The presented study of the Malenščica karst spring aquifer underlines the usefulness of the simultaneous auto- and cross-correlation analysis of daily and hourly hydrological data sets, including discharge, water level, temperature, electrical conductivity and rainfall on a regional scale. The results of the autocorrelation analysis show that the storage capacity of the spring is moderate, but this does not indicate that the system, which is characterized by prevailing conduit porosity, is less intensively karstified. This suggests that well-karstified systems of a more complex structure can have higher memory effects than less complex systems. The results of the cross-correlation analysis show that karst springs and watercourses in the investigated area react instantly and simultaneously to rather homogeneous precipitation, yet with different intensity. In such cases a crosscorrelation analysis between rainfall or ponors as inputs and springs as outputs does not provide sufficient information on the hydrogeological functioning of the system, whereas the results of a cross-correlation analysis of electrical conductivity data sets provide valuable information on its functioning and can be easily compared to those obtained by tracer tests. On the other hand, the applicability of a temperature time series in such complex karst systems is limited. A comparative analysis of the results of the time series analyses performed in successive hydrological years has proven that the selection of the hydrological year can have strong effects on the results of a time series analysis.
\end{abstract}

Keywords: autocorrelation, spectral analysis, cross-correlation analysis, karst aquifer, Malenščica spring.
Izvleček

UDK 556.33(497.4)

Gregor Kovačič: Hidrogeološka študija kraškega izvira Malenščica (JZ Slovenija) z metodo analize časovnih vrst

Kraški vodonosniki se pogosto preučujejo $\mathrm{z}$ uporabo metode analize časovnih vrst, vendar so raziskave, ki vključujejo veliko število prostorsko razporejenih časovnih vrst, zelo redke. Raziskave, ki poleg padavin, vodostajev in pretokov vključujejo tudi druge tipe hidroloških časovnih vrst, so prav tako redke. Predstavljena raziskava vodonosnika kraškega izvira Malenščica poudarja uporabnost hkratne avtokorelacijske in križnokorelacijske analize različnih dnevnih in urnih hidroloških časovnih vrst, kot so pretoki, vodostaji, temperature, specifična električna prevodnost in padavine na regionalnem nivoju. Rezultati avtokorelacijske analize kažejo, da je skladiščna zmogljivost izvira Malenščica srednja, kar ne kaže na slabšo zakraselost sistema, ki ga označuje prevladujoča kanalska prevodnost. To nakazuje, da imajo lahko dobro zakraseli sistemi kompleksnejše zgradbe daljši spominski učinek kot dobro zakraseli sistemi enostavnejše hidrogeološke zgradbe. Rezultati križnokorelacijske analize kažejo, da kraški izviri in vodotoki na preučevanem območju na precej homogene padavine reagirajo hitro in hkrati, vendar pa različno intenzivno. $\mathrm{V}$ takih primerih iz križnokorelacijske analize med padavinami ali pretoki kot vnosi ter izviri kot iznosi iz sistema ni mogoče dobiti zadovoljivih informacij o hidrogeološkem delovanju sistema, medtem ko rezultati križnokorelacijske analize časovne vrste specifične električne prevodnosti dajejo koristne informacije o njegovem delovanju in jih lahko preprosto primerjamo $\mathrm{z}$ rezultati sledilnih poizkusov. Pri kompleksnih kraških sistemih kaže časovna vrsta temperatur omejene možnosti uporabe. Primerjalna analiza rezultatov analize časovnih vrst med zaporednimi hidrološkimi leti je pokazala, da na rezultate navedene analize močno vpliva izbira preučevanega hidrološkega leta.

Ključne besede: avtokorelacija, spektralna analiza, križnokorelacijska analiza, kraški vodonosnik, izvir Malenščica.

\footnotetext{
${ }^{1}$ University of Primorska, Faculty of Humanities Koper, Titov trg 5, SI-6000 Koper, e-mail: gregor.kovacic@fhs.upr.si Received/Prejeto: 30.10 .2009
} 


\section{INTRODUCTION}

Karst aquifers and springs have been extensively studied also by means of a time series analysis, which is usually easy to perform and often provide good insights into aquifer dynamics. Mangin (1984) first applied this methodology for studying input-output relationships in karst aquifers. Since then, studies of various hydrological data sets have proven the usefulness of this method (Benavente et al. 1985; Padilla \& Pulido-Bosch 1995; Angelini 1997; Larocque et al. 1998; Molenat et al. 1999; Labat et al. 2000; Samani 2001; Amraoui et al. 2003; Jukić \& Denić-Jukić 2004; Mathevet et al. 2004; Rahnemaei et al. 2005; Massei et al. 2006; Panagopoulos \& Lambrakis 2006; Herman et al. 2009; Jemcov \& Petrič 2009). Commonly, time series analyses are performed as preliminary studies to obtain a basic understanding of a karst aquifer. However, results are often difficult to interpret due to a number of uncertainties, especially where the method is used in less investigated systems. This paper represents a step forward as it is a comprehensive regional study of the well-investigated karst aquifer of the Malenščica spring by means of time series analyses.

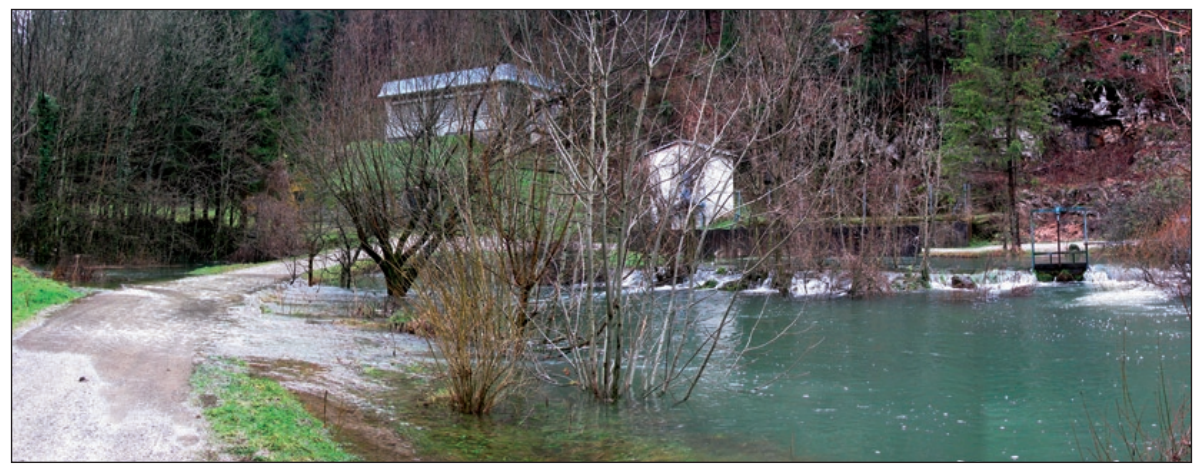

Fig. 1: The Malenščica karst spring at high waters (December 12 2008; Photo: G. Kovačič).

The Malenščica spring is an important drinking water source that supplies more than 20,000 people. Different geological, geomorphological, speleological and hydrological studies have been carried out in its catchment (e.g., Gams 1970; Gospodarič \& Habič 1976; Čar \& Gospodarič 1984; Habič 1985 and others). The results have shown that the recharge area of the spring is a binary karst hydrological system. Recently, several tracer tests were carried out to investigate the spring and its catchment (Kogovšek 1999; Kogovšek et al. 1999; Kogovšek et al. 2008; Gabrovšek et al. 2010), but its functioning in different hydrological conditions is still not sufficiently investigated. So far, no time series analysis has been performed in the area. In this study, the time series analysis comprised a univariate and bivariate correlation and spectral analysis of daily and hourly hydrological data in the relevant hydrological years 1975 and 2008 on discharge, water level, precipitation, electrical conductivity and temperature of the discussed spring as well as other measuring sites in its catchment.

In the literature, time series analyses are only rarely employed for the investigation of karst aquifers on a regional scale using a large number of spatially distributed data (e.g., Larocque et al. 1998). In addition, only a few applications deal with hourly or shorter time series (e.g., Larocque et al. 1998; Labat et al. 2000). Usually, only rainfall, water level and discharge time series are used in analyses and only a small number of applications employ also other data, such as turbidity, water temperature or electrical conductivity (e.g., Larocque et al. 1998; Amraoui et al. 2003; Massei et al. 2006; Herman et al. 2009), although they carry valuable information. Cross-correlation and cross-spectral analyses between different hydrological data sets are only rarely performed between the measuring points on sinking rivers and related springs (e.g., Larocque et al. 1998). The current knowledge of these subjects is insufficient and this study contributes to a better understanding.

The objective of this study is also to discuss the applicability of time series analysis in karst hydrology. One of the advantages of this study is that the results of the analyses performed for the Malenščica spring catchment can be properly validated by the results of other investigation techniques previously applied in the study area (e.g., recent tracing tests). A comparison of these results allows a qualitative assessment of the applicability of different hydrological data sets used in the time series analysis. Finally, a comparison between the results of time series analysis for daily and hourly data sets at the same measuring sites contributes to a generally better interpretation of the results obtained using these analyses. 


\section{HYDROLOGICAL AND HYDROGEOLOGICAL CHARACTERISTICS OF THE MALENŠČICA KARST SPRING AND ITS CATCHMENT}

The Malenščica karst spring emerges in the southern rim of the Planina polje (Fig. 2). The Planina polje (the Malenščica and Unica karst springs) is an important confluence of karst waters from three contributing subcatchments (the Cerknica polje, the Pivka basin, and the Javorniki karst plateau). Tracing test results conducted in the past show that the Malenščica spring has a catchment of $726 \mathrm{~km}^{2}$ (EARS 2009). The spring drains an allogenic catchment occupying a chain of karst poljes in the Notranjska region (the Cerknica, Loško and Babno poljes), the Pivka River basin and the Bloke plateau (Fig. 2). The spring is recharged also by autogenic pre-

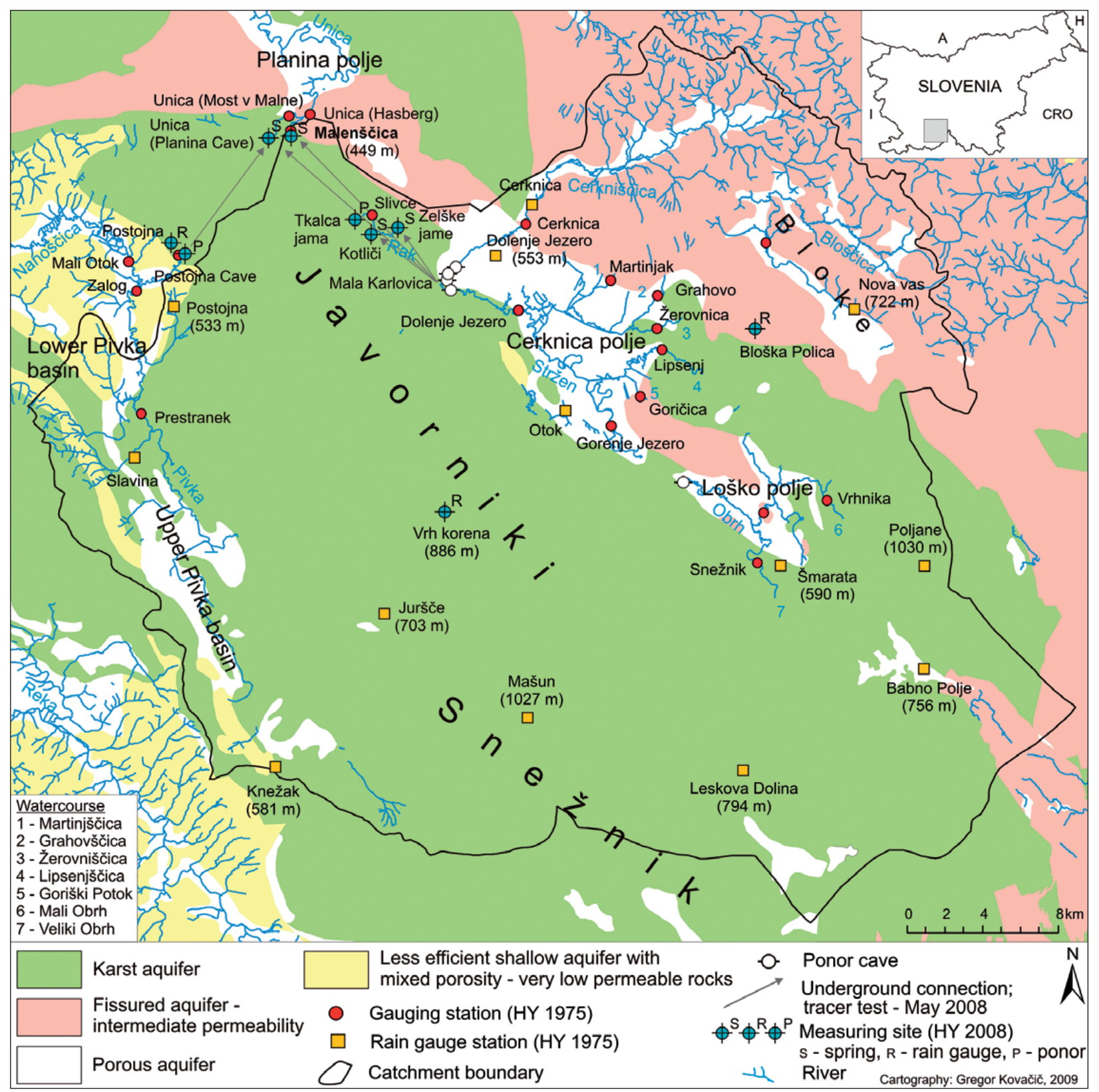

Fig. 2: Hydrogeological map of the studied area with locations of rain gauge and gauging stations included into the time series analyses for the hydrological years 1975 and 2008 and proved underground water connections according to the results of the tracer test conducted in May 2008 (Data source: EARS 2009; Gabrovšek et al. 2010). 

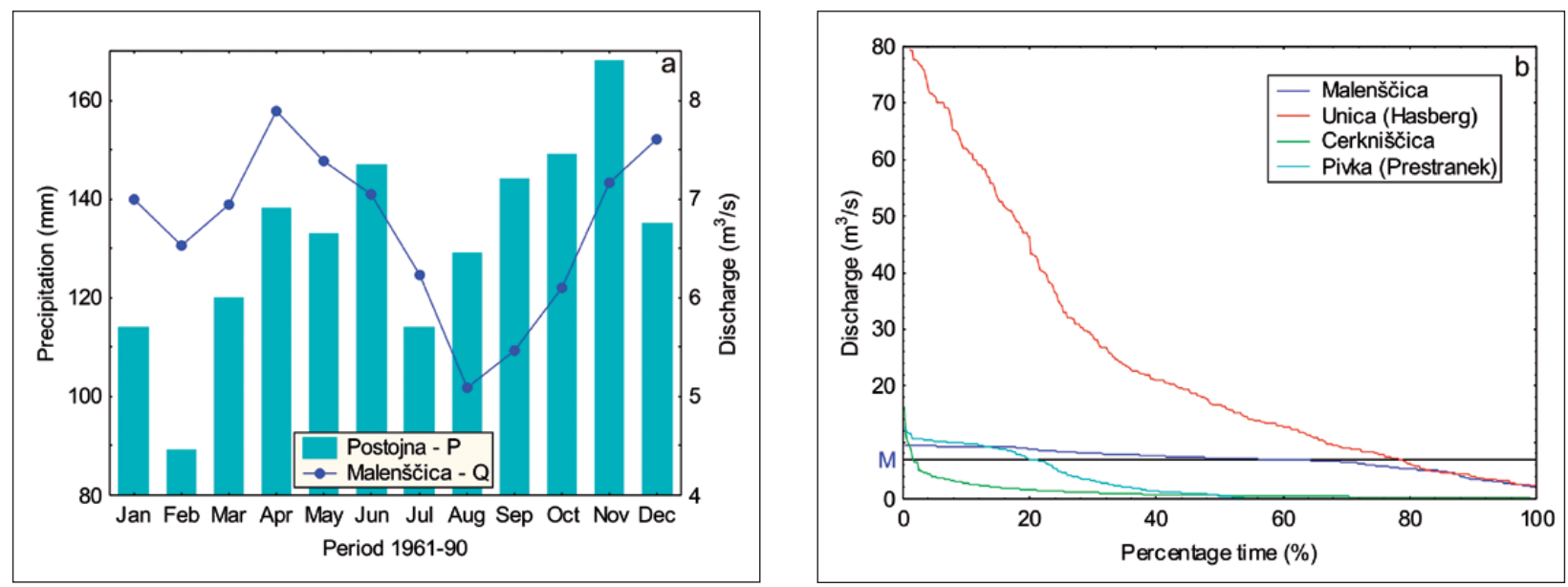

Fig. 3: a) Mean monthly precipitation (P) at Postojna rain gauge station and mean monthly discharges (Q) of the Malenščica spring in the reference period 1961-1990 (Data source: EARS 2006a, b); and b) Flow duration curves of the Malenščica, Unica, Cerkniščica and Pivka Rivers in the hydrological year 1975 (Data source: EARS 2005). With black line mean annual discharge of the Malenšcica spring in the hydrological year 1975 is labelled.

cipitation from the Dinaric Snežnik and Javorniki high karst plateaus.

In the Malenščica catchment area, rock with karstfissure porosity dominates (Cretaceous and Jurassic limestones), covering over $73 \%$ of the area; $13 \%$ of the catchment is characterized by fissured porosity (Triassic dolomites) (Fig. 2) (Kovačič 2009). In the Lower Pivka basin (Eocene flysch rocks) and in the Cerkniščica and Bloščica Rivers drainage basins (Triassic clastic formations) surface drainage occurs. Quaternary alluvial deposits are found along the rivers and at the bottom of the poljes.

The mean annual discharge of the Malenščica spring in the reference period $1961-1990$ is $6.70 \mathrm{~m}^{3} / \mathrm{s}$ (EARS 2006a). The ratio between minimum, mean and maximum discharge is 1:6.1:9. In the average hydrological year two maximums, first in April (snowmelt) and second in December (precipitation, the effect of karst retention), and two minimums, first in August and second in February (snow retention), appear (Fig. 3a). The mean annual precipitation in the period 1961-1990 in the Malenščica catchment area is estimated at $1,776 \mathrm{~mm}$ and the mean annual runoff at $1,055 \mathrm{~mm}$, with the runoff coefficient being around 60\% (Kovačič 2009).

The hydrodynamic functioning of the Malenščica spring differs from the rest of the karst springs in its catchment and from the major outflow of karst waters on the Planina polje, the Unica karst spring, where water is emerging out through a well-developed system of karst channels of the Planina Cave. Conversely, water emerging in the Malenščica spring is discharging diffusely through the system of fissures with limited outflow capacity, causing the maximum discharges of the Malenščica spring being reduced to some extent. Therefore, the record discharge value of the spring measured on October 242002 is only $11.24 \mathrm{~m}^{3} / \mathrm{s}$. On the other hand, minimum discharge is always above $1.1 \mathrm{~m}^{3} / \mathrm{s}$ (EARS 2006a). Consequently, during the periods of high waters, most of inflowing karst water to the Planina polje is directed through unobstructed underground conduits towards the Unica spring whose discharge varies between 1.08 and $90 \mathrm{~m}^{3} / \mathrm{s}$ (EARS 2006a). The particular hydrodynamic behaviour of the Malenščica spring is well expressed by the shape of its flow duration curve (Fig. 3b), showing slightly decreasing slope towards the values of the spring's baseflow. From the shape of the flow duration curve, one would expect that the memory effect of the spring in the absolute sense is very high. However, autocorrelation analysis shows rather different results, which is discussed further in the text.

\section{METHODS AND MATERIALS}

Time series analysis of hydrological data comprises the mathematical analysis of the response of a karst system to recharge and indirectly provides information re- garding the structure and functioning of karst aquifers (Mangin 1984; Box et al. 1994). Univariate analysis reveals the structure of an individual time series, either 
in terms of time (autocorrelation) or frequency domain (spectral density). The autocorrelation function quantifies the memory effect of the system, which is computed on the basis of decorrelation lag time, defined as the time at which the autocorrelation function attains a predetermined value, usually 0.2 (Mangin 1984). The structure of this function gives indirect information on the storage capacity and the karstification degree of the system. Generally, a high memory effect is often related to a large storage capacity of the system (Mangin 1984). Such types of aquifers, with a slightly decreasing slope of the autocorrelation function, are characterized by a network of smaller fissures through which the water flows at much lower velocities. In contrast, according to the cited literature (e.g., Larocque et al. 1998; Panagopoulos \& Lambrakis 2006), a well-developed karst aquifer with larger conduits and without a significant water storage capacity should correspond to a low memory system, which, however, is a rather problematic statement. The results of this study show that large and well-developed karst aquifers can also have a rather large storage capacity. In general, well-developed karst systems show much steeper autocorrelation functions and shorter decorrelation lag times. A spectral density function quantifies the regulation time, which defines the duration of the influence of the input signal and gives an indication of the length of the impulse response of the system (Larocque et al. 1998).

Cross-correlation and cross-spectral density functions imply the transformation of input signals (precipitation or concentrated infiltration via ponors) to output signals (karst spring, well) and indicate the karstification degree of a karst system. The delay, which is the time lag between lag 0 and the lag of the maximum value of the cross-correlation coefficient $\left(\mathrm{r}_{\mathrm{xy}}(\mathrm{k})\right)$, gives an estimation of the pressure pulse transfer times through the aquifer (Panagopoulos \& Lambrakis 2006). Since the transformation of the signal within a karst aquifer depends on its structure, the results of a cross-correlation analysis allow a distinction to be made between different types of karst system. Gently sloping crosscorrelograms indicate an important storage capacity and a low karstification degree of the system. On the other hand, a well-developed karst aquifer is characterized by much shorter response times (Padilla \& PulidoBosch 1995).

Firstly, we analysed daily precipitation data from 13 rain gauge stations and daily discharge (water level) data from 20 gauging stations in the hydrological year 1975. The hydrological year 1975 (from August 281974 to October 121975,411 daily values) was selected because it was the year when, since the beginning of observations in the area, the largest number of gauging stations in the Malenščica spring catchment area were operational. Data for the hydrological year 1975 was obtained from the Environmental Agency of the Republic of Slovenia (EARS 2005, 2006b). The time series analysis for this year was carried out at a daily time step and at a 130-day cutting point for autocorrelation and at a 100-day cutting point for cross-correlation analysis.

In 2007, we installed six measuring instruments in the investigated area (Fig. 2). The Malenščica spring capture and the Postojna Cave (the ponor of the Pivka River) measuring sites were equipped with automatic monitoring devices measuring discharge, temperature and electrical conductivity. TD divers measuring temperature and water level were installed at the cave of Zelške jame (the spring of the Rak River) and the cave of Tkalca jama (the ponor of the Rak River) measuring sites. In the Planina Cave (the Unica spring), a hundred metres from the entrance, a device measuring discharge, electrical conductivity and temperature, was installed. At the Kotliči karst spring a CTD diver measuring water level, electrical conductivity and temperature was installed. Precipitation data was collected from three automatic rain gauge devices installed at different locations (Vrh korena, Postojna, Bloška Polica; Fig. 2). At all measuring sites, data were recorded at half-hourly intervals, however the analysis for the hydrological year 2008 (the period from September 9 2007 to October 17 2008; 9840 hours, 411 days) was carried out at an hourly time step and at a 999-hour cutting point. Autocorrelation of the temperature time series was done at a 3,000-hour cutting point. Some hourly data sets had gaps in recordings, which were filled with white noise generated based on the time series moving averages.

In May 2008, a combined tracer test was conducted in the common catchment of the Malenščica and Unica springs (medium high discharges), whereby two different tracers were injected into the ponors of the Stržen and Pivka Rivers (the Mala Karlovica cave and the Postojna Cave respectively; Gabrovšek et al. 2010). In this paper, the results of the tracer test are used to compare the travel times of the injected tracers with the results of the cross-correlation analysis of electrical conductivity. 


\section{RESULTS}

Annual precipitation in the catchment area of the spring in the hydrological year 1975 is estimated at 2,090 mm and annual runoff at $1,228 \mathrm{~mm}$ (Kovačič 2009). Annual precipitation in the hydrological year 2008 is estimated at $1,600 \mathrm{~mm}$, estimations of annual evapotranspira- tion and runoff rates were not possible due to lack of data. In the hydrological year 1975, the discharge of the Malenščica spring varied between $2.01 \mathrm{~m}^{3} / \mathrm{s}$ and $9.54 \mathrm{~m}^{3} / \mathrm{s}$ $\left(\mathrm{Q}_{\text {mean }}=6.9 \mathrm{~m}^{3} / \mathrm{s} ;\right.$ Tab. 1$)$. In the hydrological year 2008 , mean discharge, electrical conductivity and temperature

Tab. 1: Characteristic discharges $\left(\mathrm{m}^{3} / \mathrm{s}\right)$ of the Malenščica spring and other springs and watercourses included in this study in the hydrological year 1975, and characteristic lag times (days) where the autocorrelation coefficient exceeds the 0.2 value for all gauging stations. The locations of the measuring sites are shown in Fig. 2.

\begin{tabular}{|c|c|c|c|c|}
\hline $\begin{array}{l}\text { Gauging station } \\
\text { Spring or watercourse }\end{array}$ & Mean & Minimum & Maximum & $\begin{array}{l}\text { Characteristic lag (days) } \\
\qquad\left(r_{k}=0.2\right)\end{array}$ \\
\hline $\begin{array}{l}\text { Malni } \\
\text { Malenščica }\end{array}$ & 6.9 & 2.01 & 9.5 & 32 \\
\hline $\begin{array}{l}\text { Most v Malne } \\
\text { Unica }\end{array}$ & 17.4 & 0.16 & 74.8 & 27 \\
\hline $\begin{array}{l}\text { Hasberg } \\
\text { Unica }\end{array}$ & 24.4 & 2.40 & 81.5 & 27 \\
\hline $\begin{array}{l}\text { Postojnska jama } \\
\text { Pivka }\end{array}$ & 5.7 & 0.01 & 62.0 & 21 \\
\hline $\begin{array}{l}\text { Zalog } \\
\text { Pivka }\end{array}$ & 3.9 & 0.02 & 37.7 & 23 \\
\hline $\begin{array}{l}\text { Prestranek } \\
\text { Pivka }\end{array}$ & 2.7 & 0 & 12.8 & 26 \\
\hline $\begin{array}{l}\text { Mali Otok } \\
\text { Nanoščica }\end{array}$ & 1.8 & 0.02 & 12.5 & 14 \\
\hline $\begin{array}{l}\text { Slivce } \\
\text { Rak }\end{array}$ & 13.0 & 0.05 & 45.3 & 27 \\
\hline $\begin{array}{l}\text { Cerknica } \\
\text { Cerkniščica }\end{array}$ & 1.1 & 0.08 & 16.4 & 18 \\
\hline $\begin{array}{l}\text { Martinjak } \\
\text { Martinjščica }\end{array}$ & 0.1 & 0 & 2.4 & 12 \\
\hline $\begin{array}{l}\text { Grahovo } \\
\text { Grahovščica }\end{array}$ & 0.1 & 0.01 & 1.4 & 11 \\
\hline $\begin{array}{l}\text { Žerovnica } \\
\text { Žerovniščica }\end{array}$ & 0.2 & 0.04 & 3.8 & 4 \\
\hline $\begin{array}{l}\text { Goričica } \\
\text { Goriški potok }\end{array}$ & 0.2 & 0 & 1.4 & 18 \\
\hline $\begin{array}{l}\text { Bloke } \\
\text { Bloščica }\end{array}$ & 0.5 & 0.04 & 8.1 & 13 \\
\hline $\begin{array}{l}\text { Snežnik } \\
\text { Mali Obrh }\end{array}$ & 1.5 & 0 & 12.5 & 19 \\
\hline $\begin{array}{l}\text { Pudob } \\
\text { Veliki Obrh }\end{array}$ & 4.0 & 0.61 & 26.7 & 18 \\
\hline $\begin{array}{l}\text { Vrhnika } \\
\text { Veliki Obrh }\end{array}$ & 2.2 & 0.16 & 20.6 & 18 \\
\hline $\begin{array}{l}\text { Lipsenj (water level in cm) } \\
\text { Lipsenjščica }\end{array}$ & 60 & 25 & 211 & 20 \\
\hline $\begin{array}{l}\text { Gorenje Jezero (water level in cm) } \\
\text { Stržen }\end{array}$ & 191 & 49 & 396 & 32 \\
\hline $\begin{array}{l}\text { Dolenje Jezero (water level in cm) } \\
\text { Stržen }\end{array}$ & 330 & 25 & 566 & 32 \\
\hline
\end{tabular}


of the investigated spring were $5.8 \mathrm{~m}^{3} / \mathrm{s}, 378 \mu \mathrm{S} / \mathrm{cm}$, and $9.8^{\circ} \mathrm{C}$, respectively (Tab. 2). Considering the elements of water balance for the period 1961-1990, hydrological year 1975 can be characterized as a wet year, and the hydrological year 2008 as a relatively dry year. This is worth noting because, as it has been already shown by several authors (e.g., Amraoui et al. 2003; Herman et al. 2009) and is also discussed in this study, the selection of the investigated hydrological year effects the results of the time series analyses.

\section{ANALYSIS OF DAILY TIME SERIES}

\section{AUTOCORRELATION AND SPECTRAL ANALYSIS OF DISCHARGE TIME SERIES}

Autocorrelation functions for the daily discharge values in the hydrological year 1975 show that the Malenščica spring has the largest storage capacity (Tab. 1 and Fig. 4a). The autocorrelation coefficient reaches the $r_{k}=0.2$ value after 32 days, revealing that the memory effect of its system is moderate according to Mangin's (1984) classification. The spectral density function of the spring has a regulation time of 59 days, which is characteristic of sys-
It seems that the medium memory effect of the spring is not the result of a lower karstification degree of the system, because a great part of the Malenščica spring karst system is characterised by prevailing conduit porosity. In contrast, the Unica spring, whose catchment area almost completely overlaps that of the Malenščica spring, shows a slightly lower memory effect. High underground flow velocities ranging from 30 to $240 \mathrm{~m} / \mathrm{h}$ in the common catchment of the Malenščica and Unica springs have been proven also by several tracer tests, conducted in different hydro-
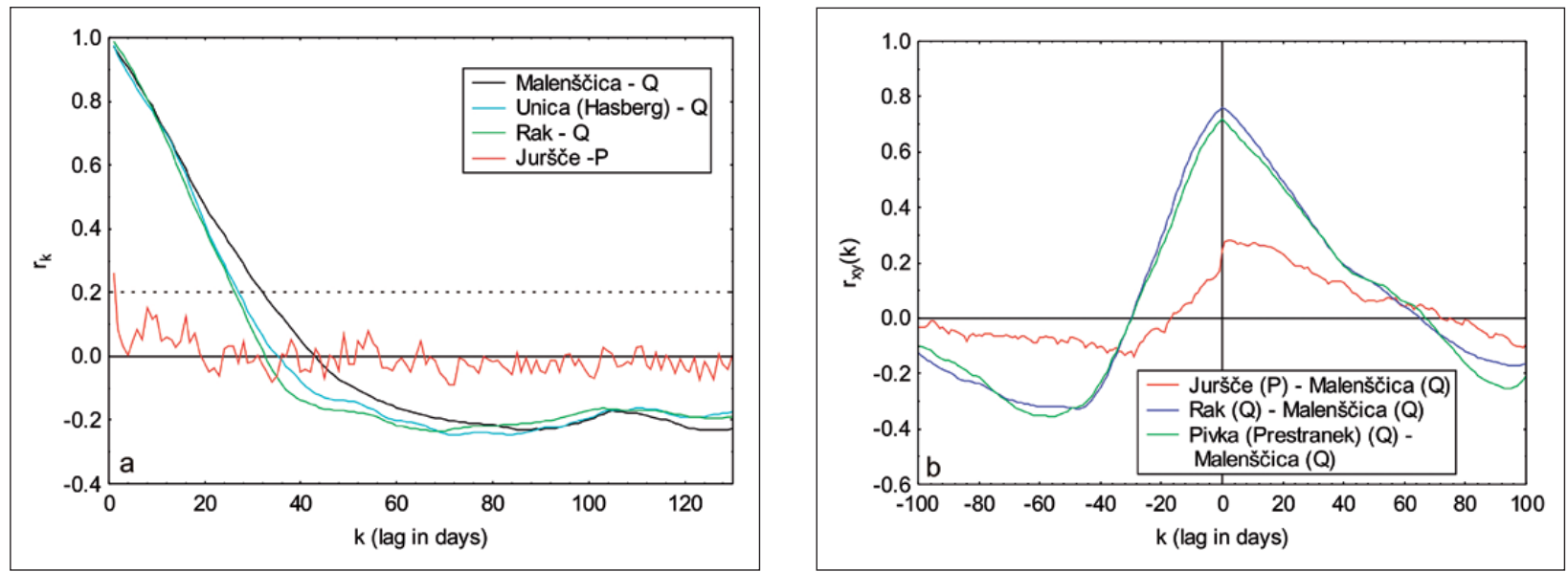

Fig. 4: Daily discharge (Q) and precipitation (P) time series in the hydrological year 1975 (Data source: EARS 2005): a) Autocorrelation functions; and b) Cross-correlation functions of discharges and precipitation as inputs and discharge of the Malenščica spring as output.

tems with a significant storage capacity. A comparison of these figures with those of other karst systems - values of $r_{k}=0.2$ varying between 37 and 117 days - (e.g., Larocque et al. 1998; Amraoui et al. 2003; Panagapoulos \& Lambrakis 2006) shows that the Malenščica spring has a slightly lower storage capacity. However, when compared with those of other investigated karst systems in Slovenia (e.g., the Korentan and Vipava karst springs) values of $r_{k}=0.2$ varying between 3 and 8 days - (Jemcov \& Petrič 2009), the spring shows a rather high memory effect. logical conditions (Kogovšek 1999; Kogovšek et al. 1999; Kogovšek et al. 2008; Gabrovšek et al. 2010). The slightly higher memory effect of the Malenščica spring, if compared to that of the Unica spring, is most probably due to the limited outflow capacities of the spring.

Smaller karst springs and systems characterized partly also by surface drainage (e.g., the Žerovniščica, Grahovščica, Martinjščica and Bloščica Rivers) have short memory effects and regulation times (Tab. 1). The autocorrelation functions of these systems indicate their 
small storage capacity and low inertia, which is otherwise typical of well-karstified systems (Mangin 1984). On the other hand, larger karst springs (e.g., the Malenščica, the Unica, the Pivka and the Rak) show longer memory effects (Tab. 1).

\section{AUTOCORRELATION ANALYSIS OF PRECIPITATION TIME SERIES}

The results of daily precipitation data analysis show that the precipitation regime within the catchment of the Malenščica spring is more or less homogeneous; the rainfall events occur almost simultaneously and in many cases, also the sums of daily precipitation at different rain gauge stations are approximately equivalent. The autocorrelation functions of daily precipitation from 13 rain gauge stations exceed the $r_{k}=0.2$ value after 1 to 2 days This means that the rainfall signal appears to be rather random (Fig. 4a).

\section{PRECIPITATION-DISCHARGE CROSS- CORRELATION ANALYSIS AND COHERENCE FUNCTION}

Delays between precipitation events and the reaction of the discharges of springs in the investigated area vary between 0 and 11 days and the values of maximum correlation coefficients vary between 0.28 and 0.73 (Figs. $4 \mathrm{~b}$ and 5). These figures indicate that, in general, the Malenščica catchment is well drained. The cross-correlation function between the precipitation station Juršče and the investigated spring shows a 2-day delay; $r_{x y}=0.28$ (Fig. 4b). The precipitation-discharge cross-correlation functions of karst springs with higher filtration capacity of rainfall signals (e.g., the Malenščica, Stržen and Rak Rivers) decrease relatively slowly with moderate slopes. In comparison to larger systems, the response of smaller and wellkarstified karst systems with small storage capacity (e.g., Žerovniščica) and systems with surface drainage characteristics (e.g., the Cerkniščica, Bloščica, Martinjščica and Grahovščica Rivers) to precipitation events is immediate and more intense. However, the duration of their pulse is shorter.

The results of the precipitation-discharge coherence function in the hydrological year 1975 show clear spatial variability. Watercourses with prevailing surface drainage (e.g., the Bloščica, Cerkniščica and Pivka Rivers) and well-karstified karst systems characterised only by autogenic recharge (e.g., the Žerovniščica and Veliki Obrh springs) behave more linearly in response to precipitation than bigger systems (e.g., the Rak, Unica and Malenščica springs), which behave less linearly (Fig. 5). However, the catchments of the bigger systems cannot be characterized as being poorly karstified. The precipitation-discharge coherence function in the investigated year varies between 0.43 (Juršče - Malenščica) and 0.76 (Poljane - Veliki Obrh). These figures are comparable with those of other karst systems with values of $\mathrm{CO}_{\mathrm{xy}}$ varying between 0.48 and 0.68 (Larocque et al. 1998; Panagapoulos \& Lambrakis 2006). The lowest value of the coherence function is calculated for the Malenščica spring, which is in accordance with its complex recharge characteristics.

\section{DISCHARGE-DISCHARGE CROSS-CORRELATION ANALYSIS AND COHERENCE FUNCTION}

Discharge-discharge cross-correlation coefficients between different pairs of gauging stations in the Malenščica catchment range between 0.50 and 0.96 , with delays of between 0 and 3 days (Fig. 5). In some cases, negative time lags for the maximum $\mathrm{r}_{\mathrm{xy}}(\mathrm{k})$ values between the gauging stations in the upper sections of the catchments and those in the lower sections are recorded (e.g., Dolenje Jezero - Hasberg). Theoretically, this would indicate that the gauging stations are not hydrogeologicaly interconnected or that the output gauging stations influence the input ones (Larocque et al. 1998). However, the results of tracer tests have proved good underground water connection between the Mala Karlovica ponor of the Stržen River (3.5 km downstream from the Dolenje Jezero gauging station) and the Unica spring (2 km upstream from the Hasberg gauging station; Gabrovšek et al. 2010). The negative time lag of maximum $r_{x y}(k)$ value therefore corresponds to the faster response of the lower positioned gauging station to recharge in comparison to the upper positioned one. A similar situation can be observed between the Dolenje Jezero (the Stržen River) and Slivce gauging stations (the Rak River) and between the Prestranek and Postojnska jama (the Postojna Cave) gauging stations on the Pivka River. As a rule, the cross-correlation coefficients are the highest between the investigated gauging stations located on the same watercourses and the lowest between ponors and springs, where underground water connections are not so direct. Despite the fact that the Malenščica spring shows the strongest correlation with the Dolenje Jezero gauging station on the Stržen $\left(r_{x y}(0)=0.94\right)$, such results cannot be attributed to the presence of direct underground connection, because prior to arriving at the Malenščica spring, the signal from the Stržen is filtrated through the hydrological system of the Rak (the Rakov Škocjan area). The high value of the correlation coefficient reflects the fact that both time series have a similar structure. The discharge variability of the Malenščica spring is small, whereas the water levels of the Stržen show only a slow increase once the water in 


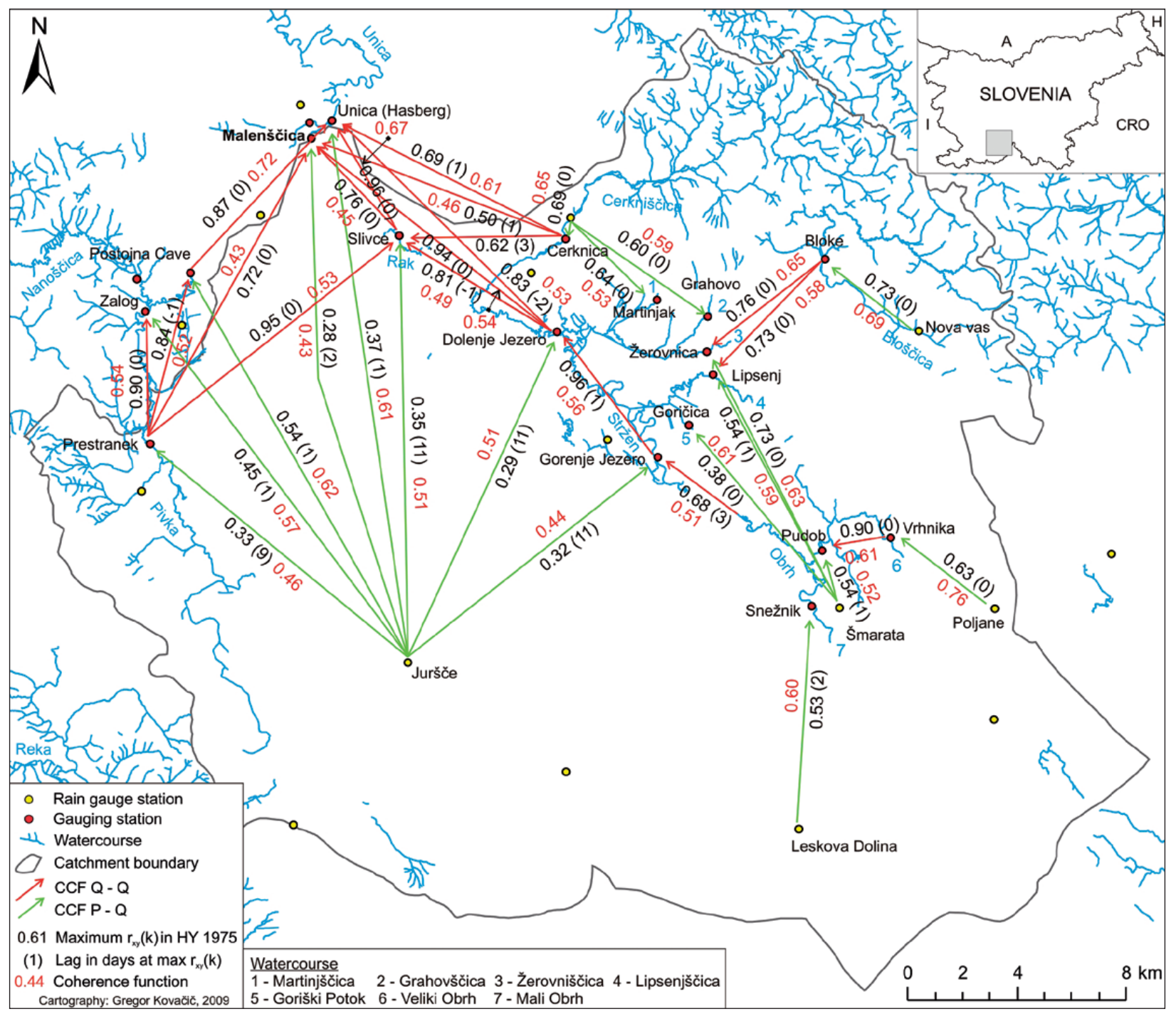

Fig. 5: Results of cross-correlation function (CCF) and coherence function of daily time series in the hydrological year 1975.

the Stržen starts to overflow and Cerknica Lake appears (Kovačič 2009). In the hydrological year 1975, the crosscorrelation coefficients between the Malenščica spring and the gauging stations in its catchment show the lowest values, which again indicate on the complexity of its aquifer.

Discharge-discharge coherence functions show higher values in the cases of well developed underground connections, as is the case with, for example, the Pivka ponor - Unica spring connection, where $\mathrm{CO}_{\mathrm{xy}}=0.87$, which is close to linearity. Direct and fast underground water connection through open and well permeable channels between these two measuring sites, with a maximum flow velocity of $240 \mathrm{~m} / \mathrm{h}$, was confirmed also by the results of water tracing (Gabrovšek et al. 2010). When less conductive underground channels are present, the values of the discharge-discharge coherence function are lower. The lowest coherence function is calculated between the Rak ponor and the Malenščica spring, where $\mathrm{CO}_{\mathrm{xy}}$ is 0.45 . For a comparison, average coherence functions between discharges of rivers and springs, calculated by Larocque et al. (1998), were between 0.65 and 0.81 . 


\section{ANALYSIS OF HOURLY TIME SERIES}

\section{AUTOCORRELATION AND SPECTRAL ANALYSIS}

In the hydrological year 2008, the memory effect of the Malenščica spring is rather low. The autocorrelation coefficient exceeds the $r_{k}=0.2$ value after 557 hours (23 days), and the $r_{k}=0$ value after 973 hours (40.5 days; Tab. 2 and Fig. 6a). However, the spectral density function has a regulation time of 1,365 hours (57 days), which corresponds to the value calculated for the hydrological year 1975 (59 days).

The shape of the autocorrelation function of precipitation at the Postojna rain gauge station decreases very rapidly and reaches the $r_{k}=0.2$ value immediately (3 hours), showing that rainfall events occur randomly (Fig. 6a). The results from the Vrh korena and Bloška Polica rain gauge stations are similar with the $r_{k}=0.2$ value exceeded after 2 hours at both stations.

At all measuring sites, an autocorrelation analysis confirms a high memory effect for the temperature $(\mathrm{T})$ and a somewhat lower one for the electrical conductivity
(EC) parameter (Tab. 2 and Fig. $6 b$ ). The $r_{k}=0.2$ value of $\mathrm{T}$ varies between 1,261 (the Rak spring) and 2,096 (the Unica spring) hours. The characteristic lag $\left(r_{k}=0.2\right)$ for $T$ of the Malenščica spring cannot be accurately calculated $\left(r_{999}=0.64\right)$. The highest memory effect of EC is calculated for the Malenšcica spring $\left(r_{999}=0.27\right)$, while the characteristic lags at the Kotliči spring, the Unica spring and the Pivka ponor are reached after 726, 332 and 248 hours respectively. The relatively high memory effect of EC of the Malenšcica spring and the small range of measured data of this parameter $(338-428 \mu \mathrm{S} / \mathrm{cm})$ show that the concentration of solutes in the investigated spring is rather stable. It appears that the mixing of the water that flows to the spring from several directions does not occur in the system of fissures in the area of outflowing, but at a point in the aquifer ahead of the spring. The high variability $(>370 \mu \mathrm{S} / \mathrm{cm})$ and the low memory effect of EC at the Pivka ponor reflect the prevailing surface drainage of the Pivka River. EC values of the Unica spring are evidently influenced by the chemical characteristics of the Pivka at its ponor.

Tab. 2: Key characteristics of the Malenščica spring as well as other springs and watercourses included in this study in the hydrological year 2008, and characteristic lag times (hours) where the autocorrelation coefficient exceeds the 0.2 value for all measuring sites. The locations of the measuring sites are shown in Fig. 2.

\begin{tabular}{|c|c|c|c|c|}
\hline $\begin{array}{l}\text { Measuring site } \\
\text { Spring or watercourse }\end{array}$ & Mean & Minimum & Maximum & $\begin{array}{l}\text { Characteristic lag (hours) } \\
\qquad\left(r_{k}=0.2\right)\end{array}$ \\
\hline \multicolumn{5}{|l|}{ Malenščica spring capture } \\
\hline Discharge $\left(\mathrm{m}^{3} / \mathrm{s}\right)$ & 5.8 & 1.60 & 9.4 & 557 \\
\hline Electric conductivity $(\mu \mathrm{S} / \mathrm{cm})$ & 378 & 338 & 428 & more than 999 \\
\hline Temperature $\left({ }^{\circ} \mathrm{C}\right)$ & 9.8 & 5.0 & 17.7 & more than 999 \\
\hline \multicolumn{5}{|l|}{ Unica spring (Planina Cave) } \\
\hline Discharge $\left(\mathrm{m}^{3} / \mathrm{s}\right)$ & 9.1 & 0.16 & 58.03 & 592 \\
\hline Electric conductivity $(\mu \mathrm{S} / \mathrm{cm})$ & 380 & 287 & 477 & 332 \\
\hline Temperature $\left({ }^{\circ} \mathrm{C}\right)$ & 9.7 & 4.2 & 14.7 & 2,094 \\
\hline \multicolumn{5}{|l|}{ Kotliči spring } \\
\hline Water level $(\mathrm{cm})$ & 219 & 41 & 738 & 292 \\
\hline Electric conductivity $(\mu \mathrm{S} / \mathrm{cm})$ & 370 & 201 & 447 & 726 \\
\hline Temperature $\left({ }^{\circ} \mathrm{C}\right)$ & 9.2 & 2.1 & 22.2 & 1,477 \\
\hline \multicolumn{5}{|l|}{ Rak spring (Zelške jame cave) } \\
\hline Water level (cm) & 37 & 0 & 174 & 635 \\
\hline Temperature $\left({ }^{\circ} \mathrm{C}\right)$ & 10.6 & 0.1 & 21.2 & 1,261 \\
\hline \multicolumn{5}{|l|}{ Rak ponor (Tkalca jama cave) } \\
\hline Water level (cm) & 344 & 5 & 2,259 & 481 \\
\hline Temperature $\left({ }^{\circ} \mathrm{C}\right)$ & 11.1 & 2.3 & 22.8 & 1,971 \\
\hline \multicolumn{5}{|l|}{ Pivka ponor (Postojna Cave) } \\
\hline Discharge $\left(\mathrm{m}^{3} / \mathrm{s}\right)$ & 3.2 & 0.50 & 31.23 & 542 \\
\hline Electric conductivity $(\mu \mathrm{S} / \mathrm{cm})$ & 394 & 204 & 574 & 248 \\
\hline Temperature $\left({ }^{\circ} \mathrm{C}\right)$ & 8.3 & 0.1 & 21.9 & 1,803 \\
\hline
\end{tabular}



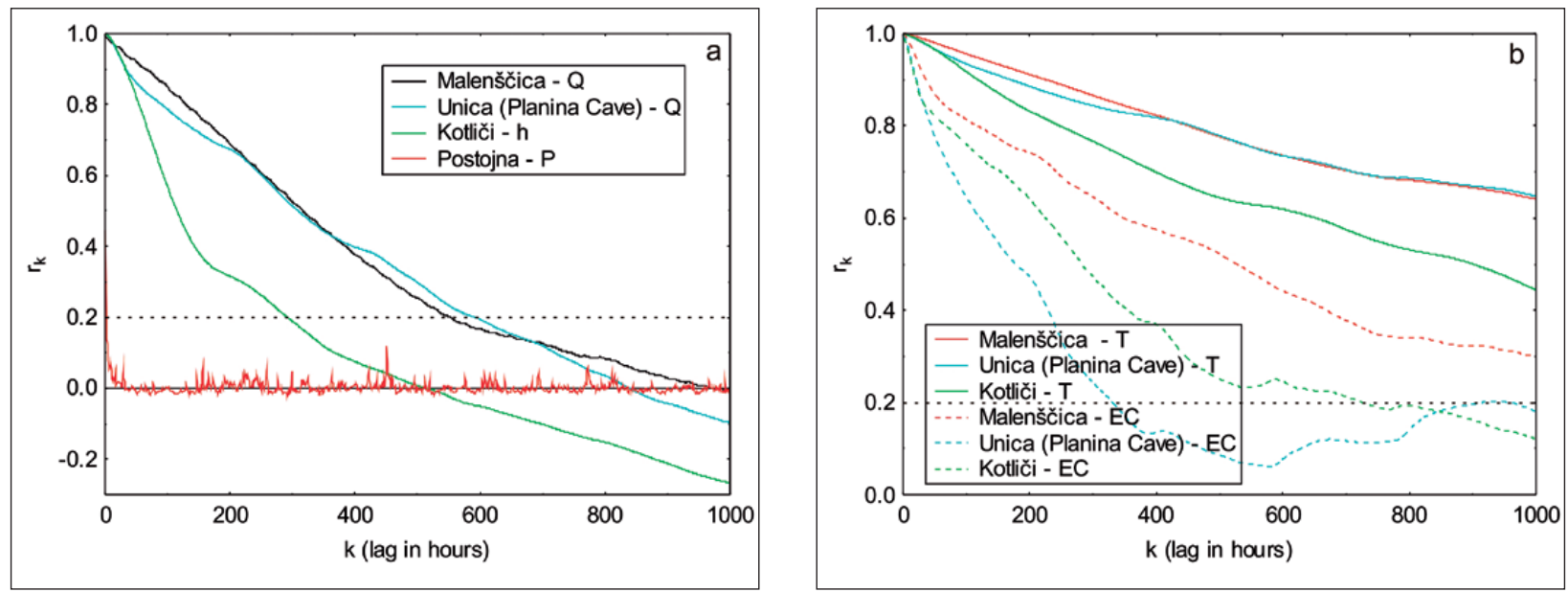

Fig. 6: Hourly time series in the hydrological year 2008: a) Autocorrelation functions of discharge (Q), water level (h) and precipitation $(P)$; and $b)$ Autocorrelation functions of temperature $(T)$ and electrical conductivity (EC).

\section{CROSS-CORRELATION ANALYSIS AND COHERENCE FUNCTION}

The Kotliči - Malenščica cross-correlation function shows no delay and immediate response $\left(\mathrm{r}_{\mathrm{xy}}(0)=0.70\right)$, meaning that both springs react simultaneously to precipitation (Figs. 7 and 8). The Pivka ponor - Unica spring cross-correlation coefficient shows very strong correlation for the discharge values $\left(\mathrm{r}_{\mathrm{xy}}(+1)=0.94\right)$, indicating fast underground connection between these two measuring sites. In contrast, the highest value of $r_{x y}$ between the Kotliči and Unica springs is reached at $\mathrm{k}=-13\left(\mathrm{r}_{\mathrm{xy}}=0.78\right)$, which corresponds to the faster recharge of the latter in comparison to the Kotliči spring (Fig. 8). The average $\mathrm{CO}_{x y}$ for the discharge-discharge relationship in the Malenščica catchment ranges between 0.39 and 0.52 , which is far from linearity. This suggests that the input signals are subjected to a relatively strong transformation.

Delays between precipitation events and the reaction of the discharges of springs and watercourses in the investigated area vary between 17 and 37 hours, with maximum $r_{x y}$ values between 0.03 and 0.19 . The delay between precipitation measured at the Postojna rain gauge station and the response of the Malenščica spring is 37 hours (Figs. 7 and 8). The average $\mathrm{CO}_{\mathrm{xy}}$ for the precipitation-discharge relationship in the Malenščica catchment ranges between 0.26 and 0.54 , which is far from linearity. The results of the precipitation-discharge cross-correlation analysis in the investigated area have confirmed the importance of the autogenic recharge of the Malenščica spring.

The results of the $\mathrm{T}$ cross-correlation analysis show strong correlations $\left(\mathrm{r}_{\mathrm{xy}}\right.$ varying between 0.90 and 0.96 ) and with no delay, with the exception of the Rak ponor - the Unica spring $(k=-46)$ and the Rak spring - the Rak

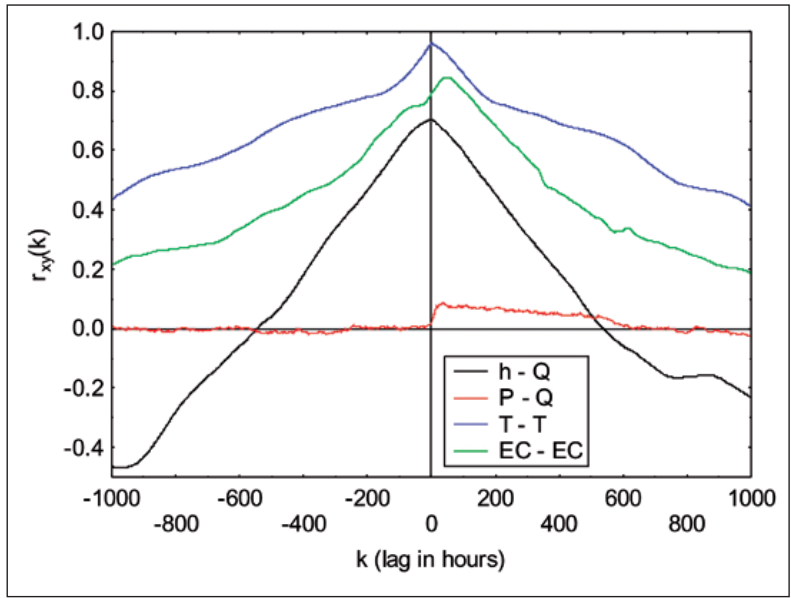

Fig. 7: Hourly time series in the hydrological year 2008: cross-correlation functions of precipitation $(P)$ measured at the Postojna measuring site, the water level $(h)$, temperature $(T)$ and electrical conductivity (EC) values of the Kotlici spring as inputs, and the discharge (Q), temperature (T) and electrical conductivity (EC) values of the Malenščica spring as outputs.

ponor $(\mathrm{k}=+4)$ correlations (Fig. 8). The average $\mathrm{CO}_{\mathrm{xy}}$ for the T-T relationship shows a higher degree of linearity (varying between 0.40 and 0.77 ) than other parameters, proving that the $\mathrm{T}$ signals are relatively linearly transmitted throughout the Malenščica hydrological system.

The EC cross-correlation coefficients vary between 0.53 and 0.85 (Fig. 8). The maximum $r_{x y}(k)$ value for EC between the Kotliči and Malenščica springs is reached after 49 hours $\left(r_{x y}=0.85\right.$; Figs. 7 and 8). The results of the EC cross-correlation analysis between the Pivka ponor and the Kotliči spring as inputs and the Unica spring as output coincide with those of the discharge-discharge cross-correlation analysis. The maximum $\mathrm{r}_{\mathrm{xy}}$ value of 


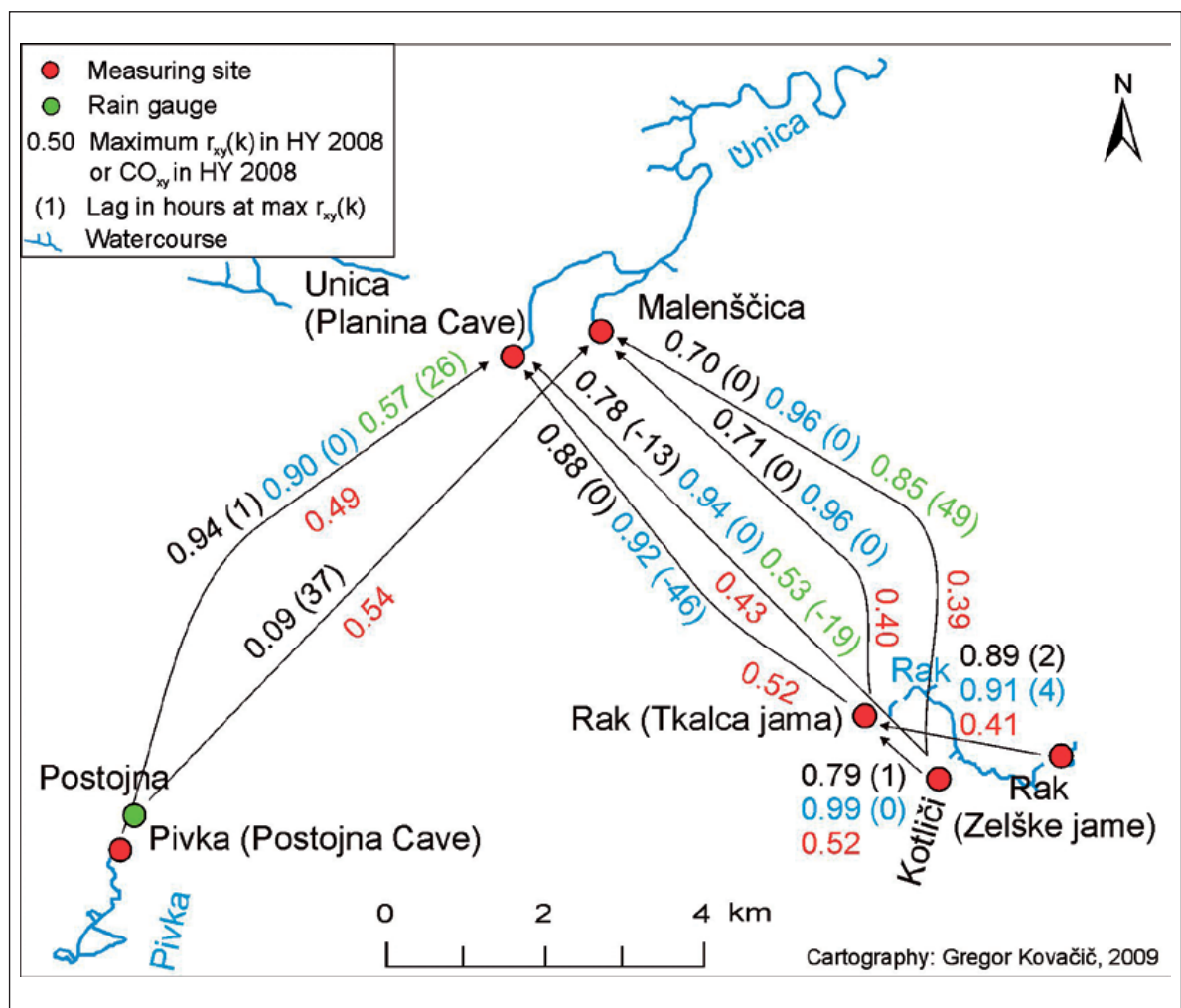

Fig. 8: Cross-correlation coefficients for the hourly discharge (black), T (blue) and EC (green) time series in the hydrological year 2008. Discharge-discharge, water level-discharge and precipitationdischarge coherence function values are indicated in red.
EC between the Pivka ponor and the Unica spring is reached after 26 hours $\left(\mathrm{r}_{\mathrm{xy}}=\right.$ 0.57 ), while the maximum $\mathrm{r}_{\mathrm{xy}}$ value of EC between the Kotliči spring and the Unica spring is reached at $\mathrm{k}=-19$ $\left(r_{x y}=0.53\right)$. For a comparison, the maximum values of the $r_{x y}$ between discharges of rivers and springs, calculated by Larocque et al. (1998), are between 0.70 and 0.80 . The average values of $\mathrm{CO}_{\mathrm{xy}}$ for the EC-EC relationships between individual measuring sites (0.36-0.42) indicate a lower degree of linearity in the investigated area. This suggests that the mixing of water with different chemical composition in the catchments of individual springs occurs and that the signals of EC cannot be effectively transmitted between the ponors and associated springs.

\section{DISCUSSION AND CONCLUSION}

The results of the time series analysis for hourly data in the hydrological year 2008 are somewhat different from those performed for daily data in the hydrological year 1975. Since the former year can be characterized as a dry year and the latter as a relatively wet year, a straightforward comparison of the obtained results for both years is not possible. Nevertheless, the results for both years provide general information concerning the hydrogeological functioning of the Malenščica aquifer.

A comparative analysis of the results of the time series analysis performed for the Malenščica and Unica springs in the successive hydrological years 1997-2002 reveals clear differences in the calculated characteristic lags $\left(r_{k}=0.2\right)$ and in the calculated lags and values of maximum precipitation-discharge cross-correlation coefficients. The characteristic lags of the Malenščica spring for individual hydrological years in the period 1997-2002 vary between 16 and 80 days (Fig. 9a), whereas the maximum precipitation-discharge cross-correlation coefficients vary between 0.17 and 0.28 with lags from 0 to 17 days (Fig. 9b). It is worth noting that these figures show no correlation with the corresponding mean yearly discharges of the spring. The same results can be observed for the Unica spring. This analysis clearly shows that the selection of the hydrological year (the structure of time series itself) can have strong effects on the results of a time series analysis. In this regard, in order to obtain a more general image of the functioning of a karst system in absolute terms, it is important to consider longer hydrological data sets (more successive hydrological years), since they reflect more average conditions.

Methodologically important is that the results of the cross-correlation analysis of hourly EC values between the Kotliči and Malenščica springs and between the Pivka ponor and the Unica spring are in line with the results of the tracer test conducted in May 2008 (Gabrovšek et al. 2010). The time lag between the two springs clearly shows that the chemical characteristics of the Kotliči spring are being transferred towards the observed spring $\left(\mathrm{r}_{\mathrm{xy}}(+49)=0.85\right.$; Fig. 8). The apparent 

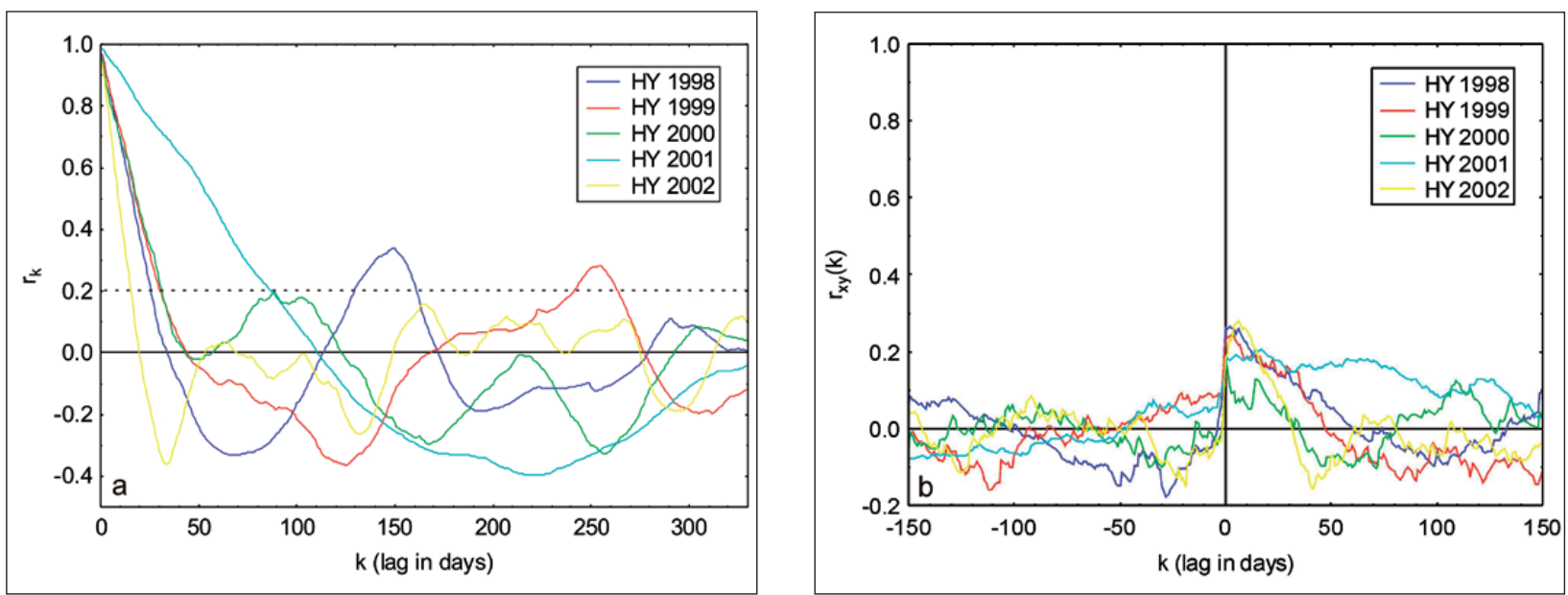

Fig. 9: Daily time series during five successive hydrological years in the period 1997-2002: a) Autocorrelation functions of the Malenščica discharge data sets; and b) Cross-correlation functions between precipitation measured at the Juršče rain gauge station as input and the discharge of the Malenščica spring as output.

velocity of water particle flow between these two springs is $92 \mathrm{~m} / \mathrm{h}$, which is in accordance with the calculated apparent dominant velocity of Uranine transfer from the Mala Karlovica ponor to the Malenščica spring (101 m/ h). From the results of the cross-correlation analysis of EC between the Kotliči and Malenščica springs $\left(\mathrm{r}_{\mathrm{xy}}(+38)\right.$ $=0.58$ ) during the execution of the tracer test actual particle flow velocity (solute transport) is calculated (118 $\mathrm{m} / \mathrm{h}$ ). This value is alike to the calculated velocity of the tracer breakthrough $(119 \mathrm{~m} / \mathrm{h})$. Analogically, the results of the cross-correlation analysis of EC between the Pivka ponor and the Unica spring $\left(\mathrm{r}_{\mathrm{xy}}(+26)=0.57\right)$ in the hydrological year 2008 (Fig. 8) are also in line with the results of the Amidorhodamine G breakthrough time (29 hours). These figures show that in certain hydrological conditions the EC time series could be used to replace or plan tracer tests, which has previously been established also by Larocque et al. (1998).

This study has shown that in the case of aquifers with quick responses to precipitation events, rainfallspring and ponor-spring cross-correlation analyses do not provide sufficient information on the hydrogeological functioning of the system. In such cases electrical conductivity data sets provide valuable information. On the other hand, the applicability of a temperature time series is only limited. In comparison to EC, the results of a $\mathrm{T}$ cross-correlation analysis provides only scarce information, especially in the case of karst systems, where substantial underground mixing of water inflowing from different directions occurs and intensive thermal exchanges between the water and the bedrock are present. Water temperature is not a conservative tracer and the interpretation of these time series is delicate in karst systems (Larocque et al. 1998). Since the current knowledge of this subject is insufficient, some work still needs to be done in the future, especially with the aim to confirm the applicability of electrical conductivity data sets in time series analyses as an alternative method to water tracing between ponors and related springs.

The work presented here underlines the usefulness of the simultaneous time series analysis of various daily and hourly hydrological data sets on a regional scale. Results of the analysis has shown that the size and complexity of a catchment area can influence the memory effect and the storage capacity of individual karst springs; typically, the storage capacity of larger systems and systems characterised by a more complex structure is greater and vice versa. A noteworthy conclusion and contribution of this study is that not all karst systems characterized by a higher memory effect should be considered as poorly karstified. In this regard, caution needs to be used when classifying karst systems into groups on the basis of the results of a time series analysis. Therefore it is essential that the results of a time series analysis be interpreted together with the results of other methods used in karst hydrology. 


\section{ACKNOWLEDGMENT}

The research was carried out in cooperation with the Karst Research Institute of the SRC SASA, Postojna, Slovenia. The author expresses his sincere thanks to Dr. Metka Petrič, for her help, as well as other employees of the above-mentioned institution for their work in the framework of this research. Sincere thanks are also due to Mr. Peter Frantar from the Environmental Agency of the Republic of Slovenia for providing the requested hydrological data.

\section{REFERENCES}

Amraoui, F., Razack, M. \& L. Bouchaou, 2003: Turbidity dynamics in karstic systems. Example of Ribaa and Bittit springs in the Middle Atlas (Morocco).- Hydrological Sciences Journal, 48, 6, 971-984.

Angelini, P., 1997: Correlation and spectral analysis of two hydrogeological systems in Central Italy.- Hydrological Science Journal, 42, 3, 425-438.

Benavente, J., Pulido-Bosch, A. \& A. Mangin, 1985: Application of correlation and spectral procedures to the study of the discharge in a karstic system (Eastern Spain).- In: Gunay, G. \& A.I. Johnson (eds.) Karst water resources - Proceedings of the AnkaraAntalya Symposium, July 1985, 67-75, Ankara.

Box, G.E.P., Jenkins, G.M. \& C. Reinsel, 1994: Time series analysis: forecasting and control, $3^{\text {rd }} \mathrm{ed}$.- Prentice Hall, pp. 598, New Jersey.

Čar, J. \& R. Gospodarič, 1984: O geologiji krasa med Postojno, Planino in Cerknico.- Acta carsologica, 13, 91-106.

Environmental Agency of the Republic of Slovenia (EARS), 2005: Daily discharges and water levels at the Malni (the Malenščica spring), Most $\mathrm{v}$ Malne (the Unica), Hasberg (the Unica), Postojna Cave (the Pivka), Zalog (the Pivka), Prestranek (the Pivka), Mali Otok (the Nanoščica), Slivce (the Rak), Cerknica (the Cerkniščica), Martinjak (the Martinjščica), Grahovo (the Grahovščica), Žerovnica (the Žerovniščica), Goričica (the Goriški Potok), Bloke (the Bloščica), Snežnik (the Mali Obrh), Šmarata (the Mali Obrh), Pudob (the Veliki Obrh), Vrhnika (the Veliki Obrh), Lipsenj (the Lipsenjščica), Gorenje Jezero (the Stržen), Dolenje Jezero (the Stržen) and Vodonos (the Stržen) gauging stations for years 1974 and 1975. The archive of the Environmental Agency of the Republic of Slovenia, Ljubljana.
Environmental Agency of the Republic of Slovenia (EARS), 2006a: Minimum, mean and maximum monthly discharges at the Malni (the Malenščica spring) and Hasberg (the Unica) gauging stations for the period 1961-1990. The archive of the Environmental Agency of the Republic of Slovenia, Ljubljana.

Environmental Agency of the Republic of Slovenia (EARS), 2006b: Daily precipitation amounts at the Babno Polje, Cerknica, Dolenje Jezero, Juršče, Knežak, Leskova Dolina, Mašun, Nova vas (Bloke), Otok (the Cerknica polje), Poljane (Stari trg), Postojna, Slavina and Šmarata rain gauge stations for years 1974, 1975 and for the period 1961-1990. The archive of the Environmental Agency of the Republic of Slovenia, Ljubljana.

Environmental Agency of the Republic of Slovenia (EARS), 2009: Digital data on water.- [Online] Available from: http://gis.arso.gov.si [Accessed $1^{\text {st }}$ July 2009].

Gabrovšek, F., Kogovšek, J., Kovačič, G., Petrič, M., Ravbar, N. \& J. Turk, 2010: Recent results of tracer tests in the catchment of the Unica River (SW Slovenia).Acta carsologica, 39, 1, 27-37.

Gams, I., 1970: Maksimiranost kraških podzemeljskih pretokov na primeru ozemlja med Cerkniškim in Planinskim poljem.- Acta carsologica, 5, 171-187.

Gospodarič, R. \& P. Habič, (eds.), 1976: Underground water tracing: Investigations in Slovenia 1972-1975.Third International Symposium of Underground Water Tracing (3. SUWT), pp. 312, Ljubljana, Bled.

Habič, P., 1985: Vodna gladina v Notranjskem in Primorskem krasu.- Acta carsologica, 13, 37-78.

Herman, E.K., Toran, L. \& W.B. White, 2009: Quantifying the place of karst aquifers in the groundwater to surface water continuum: a time series analysis study of storm behaviour in Pennsylvania water resources.- Journal of Hydrology, 376, 307-317. 
Jemcov, I. \& M. Petrič, 2009: Measured precipitation vs. effective infiltration and their influence on the assessment of karst systems based on results of the time series analysis.- Journal of Hydrology, 379, 3-4, 304-314.

Jukić, D. \& V. Denić-Jukić, 2004: A frequency domain approach to groundwater recharge estimation in karst.- Journal of Hydrology, 289, 95-110.

Kogovšek, J., 1999: Nova spoznanja o podzemnem pretakanju vode v severnem delu Javornikov (visoki kras).- Acta carsologica, 28, 1, 161-200.

Kogovšek, J., Knez, M., Mihevc, A., Petrič, M., Slabe, T. \& S. Šebela, 1999: Military training area in Kras (Slovenia).- Environmental Geology, 38, 1, 69-76.

Kogovšek, J., Prelovšek, M. \& M. Petrič, 2008: Underground water flow between Bloke plateau and Cerknica polje and hydrologic function of Križna jama, Slovenia.- Acta carsologica, 37, 2-3, 213-225.

Kovačič, G., 2009: Hydrology of the Malenščica karst spring and its catchment.- PhD thesis. University of Primorska, Faculty of Humanities Koper, pp. 356.

Labat, D., Ababou, R. \& A. Mangin, 2000: Rainfall-runoff relations for karstic springs. Part I: convolution and spectral analyses.- Journal of Hydrology, 238, 123-148.

Larocque, M., Mangin, A., Razack, M. \& O. Banton, 1998: Contribution of correlation and spectral analyses to the regional study of a large karst aquifer (Charente, France).- Journal of Hydrology, 205, 217-231.

Mangin, A., 1984: Pour une meilleure connaissance des systèmes hydrologiques à partir des analyses corrélatoire et spectrale.- Journal of Hydrology, 67, 25-43.
Massei, N., Dupont, J.P., Mahler, B.J., Laignel, B., Fournier, M., Valdes, D. \& S. Ogier, 2006: Investigating transport properties and turbidity dynamics of a karst aquifer using correlation, spectral, and wavelet analyses.- Journal of Hydrology, 329, 244-257.

Mathevet, T., Lepiller, M. \& A. Mangin, 2004: Application of time-series analyses to the hydrological functioning of an Alpine karstic system: the case of Bange-L'Eau-Morte.- Hydrology and Earth System Sciences, 8, 1051-1064.

Molenat, J., Davy, P., Gaseuel-Odoux, C. \& P. Durand, 1999: Study of three subsurface hydrologic systems based on spectral and cross-spectral analysis of time series.- Journal of Hydrology, 222, 152-164.

Padilla, A. \& A. Pulido-Bosch, 1995: Study of hydrographs of karstic aquifers by means of correlation and cross-spectral analysis (France, Spain).- Journal of Hydrology, 168, 73-89.

Panagopoulos, G. \& N. Lambrakis, 2006: The contribution of time series analysis to the study of the hydrodynamic characteristics of the karst systems: Application on two typical karst aquifers of Greece (Trifilia, Almyros Crete).- Journal of Hydrology, 329, 368-376.

Rahnemaei, M., Zare, M., Nematollahi, A.R. \& H. Sedhi, 2005: Application of spectral analysis of daily water level and spring discharge hydrographs data for comparing physical characteristics of karst aquifers.- Journal of Hydrology, 311, 106-116.

Samani, N., 2001: Response of karst aquifers to rainfall and evaporation, Maharlu basin, Iran.- Journal of Cave and Karst Studies, 63, 1, 33-40. 